\title{
A study on the performance and emission of diesel engine with Jatropha biodiesel and its blends at different engine load
}

\author{
Ahmed Jado ${ }^{1}$ and Jinming Pan $^{2}$ \\ ${ }^{1}$ Mansoura University \\ ${ }^{2}$ Zhejiang University
}

June 26, 2020

\begin{abstract}
An experimental study has been done to examine the performance and emission of a diesel engine using different blend ratios of Jatropha oil methyl ester at different engine speeds. At each speed, the engine was operated at no load, quarter, half, three quarters, and full load for different blending ratios. The performance parameters evaluated include Brake Power (BP), Brake Mean Effective Pressure (BMEP), brake specific fuel consumption (BSFC), air to fuel ratio (AFR), excess air factor, brake thermal efficiency, volumetric efficiency and the temperature of exhaust gas whereas exhaust emissions include specific emissions of $\mathrm{O} 2, \mathrm{CO}, \mathrm{CO} 2$, and $\mathrm{NOx}$. Biodiesel blends result in a decrease of brake power by $30.8 \%$, decreases in air to fuel ratio by $18 \%$, decreases in brake thermal efficiency by $21 \%$, decreases in volumetric efficiency by $10.7 \%$ and increases in brake specific fuel consumption by $32.18 \%$. Specific emission of O2, CO, and NOx increases with increasing the percentage of biodiesel in fuel blends. Specific emission of CO2 decreases with increasing the rate of biodiesel in fuel blends. The results suggest that biodiesel obtained from non-edible oil like Jatropha could be a decent substitute to diesel fuel in the diesel engine.
\end{abstract}

Ahmed Jado ORCID: 0000-0001-9585-3433

\section{A study on the performance and emission of diesel engine with Jatropha biodiesel and its blends at different engine load}

Ahmed $\mathrm{Jado}^{\mathrm{a}, *}$, Jinming $\mathrm{Pan}^{\mathrm{b}}$

${ }^{a}$ Mansoura University, Department of Agricultural Engineering,

Mansoura 35516, Egypt

b Zhejiang University, Department of Biosystems Engineering,

Hangzhou 310058, China

*Corresponding author: jado@mans.edu.eg

Abstract

An experimental study has been done to examine the performance and emission of a diesel engine using different blend ratios of Jatropha oil methyl ester at different engine speeds. At each speed, the engine was operated at no load, quarter, half, three quarters, and full load for different blending ratios. The performance parameters evaluated include Brake Power $\left(\mathrm{B}_{\mathrm{P}}\right)$, Brake Mean Effective Pressure (BMEP), brake specific fuel consumption (BSFC), air to fuel ratio (AFR), excess air factor, brake thermal efficiency, volumetric efficiency and the temperature of exhaust gas whereas exhaust emissions include specific emissions of $\mathrm{O}_{2}, \mathrm{CO}, \mathrm{CO}_{2}$, and $\mathrm{NO}_{\mathrm{x}}$. Biodiesel blends result in a decrease of brake power by $30.8 \%$, decreases in air to fuel ratio by $18 \%$, decreases in brake thermal efficiency by $21 \%$, decreases in volumetric efficiency by $10.7 \%$ and 
increases in brake specific fuel consumption by $32.18 \%$. Specific emission of $\mathrm{O}_{2}, \mathrm{CO}$, and $\mathrm{NO}_{\mathrm{x}}$ increases with increasing the percentage of biodiesel in fuel blends. Specific emission of $\mathrm{CO}_{2}$ decreases with increasing the rate of biodiesel in fuel blends. The results suggest that biodiesel obtained from non-edible oil like Jatropha could be a decent substitute to diesel fuel in the diesel engine.

Keywords: Biofuel; Jatropha biodiesel; Engine performance; Emissions analysis; Engine load

\section{Introduction}

The increasing of environmental concerns and the reduced availability of fuel in recent years provide considerable incentives to develop alternative fuels from renewable sources that are more economical and environmentally acceptable. Numerous researchers have tried to generate vegetable oil-based derivatives that approximate the characteristics and performance of petroleum-based diesel fuel (Che Mat, Idroas, Hamid, \& Zainal, 2018; Franco \& Nguyen, 2011; Jakub et al., 2018; Prasad, Singh, \& Prasad, 2020; Uyumaz, 2020).

Rudolph Diesel used vegetable oil (peanut oil) as a fuel in a diesel engine on August 10, 1893 (Jayed et al., 2011). The major problem with the direct use of vegetable oils as fuel into compression ignition (CI) engines is their high viscosity, which causes a problem such as more reduced atomization of the fuel spray and less accurate operation of the fuel injectors in the engine (Bhuiya, Rasul, Khan, Ashwath, \& Azad, 2016). The issue of higher viscosity can be overcome by four methods, such as dilution (blending), heating (thermal cracking), emulsification, and transesterification (Balat, 2011; Silitonga et al., 2011). Esters of fatty acids (biodiesel), derived from the transesterification of vegetable oils have properties similar to petroleum-based diesel fuel (Hoekman, Broch, Robbins, Ceniceros, \& Natarajan, 2012; Mahmudul et al., 2017). Transesterification one of the most economical and efficient processes to produce biodiesel and leads to mono-alkyl esters of vegetable oils and fats (Atabani et al., 2013). Biodiesel can be classified into three ages, dependent on the source from which they are acquired. First-generation biodiesel is gotten from an edible feedstock like rapeseed or soybean oil. The second-generation biodiesel is produced from non-edible oils, for example, neem or jatropha oil. Sources with higher oil substance are appropriate for second-generation biodiesel. The main points of interest of second-generation biodiesel are eradicated food imbalance, decreased biodiesel production price, less requirement of land for cultivation, and eco-friendly nature (Ambat, Srivastava, \& Sillanpää, 2018; Mahdavi, Abedini, \& Darabi, 2015). The third generation biodiesel is produced from microalgae (Arif et al., 2020; Tariq, Ali, \& Khalid, 2012; Turkkul, Deliismail, \& Seker, 2020).

Many studies have been carried out on biodiesels and their blends with mineral diesel (Alptekin, Canakci, Ozsezen, Turkcan, \& Sanli, 2015; Amid et al., 2020; Debnath, Sahoo, \& Saha, 2013; Dharma, Ong, Masjuki, Sebayang, \& Silitonga, 2016; Najafi, 2018; Sharma Dugala, Singh Goindi, \& Sharma, 2020; Verma et al., 2020). The use of vegetable oil results in increased fuel consumption i.e., increased brake specific fuel consumption (BSFC). Various studies found higher $\mathrm{CO}$ and $\mathrm{HC}$ emissions with vegetable oils and their blends, and lower NOx and particulate emissions compared to mineral diesel (A. K. Agarwal, Singh, \& Maurya, 2017; Al-Shemmeri \& Oberweis, 2011; Devaraj, Yuvarajan, \& Vinoth Kanna, 2020; Misra \& Murthy, 2011; Seraç, Aydın, Yılmaz, \& Şevik, 2020; Xiao et al., 2020). Engine performance and emissions tests conducted on biodiesels and their mixtures as potential CI engine fuels (Ashour \& Elwardany, 2020; Damodharan, Sathiyagnanam, Rana, Kumar, \& Saravanan, 2018; Datta \& Mandal, 2017; Gad \& Jayaraj, 2020; Jiaqiang et al., 2017). Jatropha is non-edible and finds no significant use. The Jatropha tree is an oil crop that is grown widely in areas of Southwest China, and also the total planted space of the crop is currently over one million acres. The plant is easy to grow in uncultivated lands, so it is an excellent potential feedstock for biodiesel production.

Several investigators (D. Agarwal \& Agarwal, 2007; Chauhan, Kumar, \& Cho, 2012; Chauhan, Kumar, Du Jun, \& Lee, 2010; Kavitha, Beemkumar, \& Rajasekar, 2019; Madiwale, Karthikeyan, \& Bhojwani, 2018) conducted experiments on Jatropha oil methyl esters and its blends with mineral diesel, however, few investigations have studied the performance and emissions of diesel engines with Jatropha oil methyl ester (JME) at different loads and speeds, and very few of them conducted experiments using $100 \%$ straight Jatropha oil methyl ester. 
The aim of this study is, therefore, to examine performance and emissions of a light-duty diesel engine with petroleum diesel fuel using different blend ratios of JME at different loads and speeds to find out their suitability as a diesel engine fuel.

1. Experimental section

2.

\section{Fuel properties}

The Jatropha oil methyl ester (JME) biodiesel was obtained and converted from Jatropha seeds. Firstly, Jatropha oil was taken from Jatropha seeds. Then JME biodiesel is created through a chemical process named Transesterification whereby the glycerin is left from the Jatropha oil. The process leaves behind two products - Jatropha oil methyl ester and glycerin. Jatropha oil has a typical molecular structure as other vegetable oils called triglyceride. Mainly found fatty acids in Jatropha oil are Linoleic, Oleic, Palmitic, and Stearic acids. Biodiesel has been approximated as a single component fuel of Oleic acid $\left(\mathrm{C}_{18} \mathrm{H}_{34} \mathrm{O}_{2}\right)(\mathrm{Li}$, Yang, Zhou, \& Yu, 2019). The Jatropha oil before transesterification has a chemical formula of $\mathrm{C}_{56} \mathrm{H}_{101} \mathrm{O}_{6}$. To understand effects of biodiesel blend ratio on the performance and emissions of diesel engines in details, six kinds of fuels (diesel, B20, B40, B60, B80, and B100 fuels) were tested in this study. The different Physico-chemical properties of diesel and Jatropha biodiesel are summarized in Table 1.

\section{Test engine and equipment}

The engine utilized in this study is a naturally aspirated, two cylinders, four-stroke, direct injection, aircooled Diesel engine. The maximum power of this engine is $17 \mathrm{~kW}$. It is a typical engine widely used in the agricultural sector to drive water pumps. The engine is coupled with an AC alternator. The detailed specifications of the engine are given in Table 2. The AC alternator is used for loading the engine through a resistive load bank. The load bank consists of twelve heating coils (1000 W of each one). These twelve heating coils are used as the full load of the engine of $12 \mathrm{~kW}$. Also, every three coils are connected together in series in one group to represent a quarter of the engine load, so there are four groups connected by an on/off switch of the heating coil. The performance and emissions of the engine are obtained at different engine speeds, namely 500, 750, 1000, 1250 and $1500 \mathrm{rpm}$. At each speed, the engine was operated at no load, quarter, half, three quarters and full load for different blending ratios of diesel and biodiesel fuels. Fuel consumption, inlet air-flow rate, and exhaust temperatures were also measured. The exhaust gas composition was measured using IMR 2800P gas analyzer. The measurement range and accuracy of the exhaust analyzer are given in Table 3 .

The schematic layout of the experimental system is shown in Fig.1. The engine must be a startup with the diesel fuel and then left being run at no load for about 15 min for warming up. Similarly while switching the engine off, it is shifted back to mineral diesel 15 min before stopping. By doing this, cold starting problems of the engine can be avoided to a large extent.

1. Results and discussion

2.

\section{Engine performance characteristics}

The engine performance parameters, brake power, brake mean effective pressure, brake specific fuel consumption, air to fuel ratio, excess air factor, brake thermal efficiency, and volumetric efficiency are obtained versus engine loads at different speeds.

Brake Power versus Engine load 
The engine power depends on the output torque and engine speed. The engine output power increases with the increase in engine speed as shown in Fig.2. This is due to keeping a constant output torque of the engine as long as the engine load is maintained constant. Figure 3 shows the variation of brake power versus engine load for Diesel and biodiesel fuel blends at $1500 \mathrm{rpm}$. The engine output power gradually decreased as biodiesel increases in the fuel blends. This may be due to increases in exhaust gas temperature for biodiesel fuel blends than Diesel fuel, which lead to decreases in volumetric efficiency of biodiesel blends. Moreover, the lower heating value of biodiesel fuel blends than Diesel fuel may also be a cause of this decrease in brake Power $\left(\mathrm{B}_{\mathrm{P}}\right)$. Also, due to bad fuel characteristics of biodiesel fuel as higher viscosity, higher density, and poor volatility. That's mean that a poor atomization and combustion characteristic of biodiesel fuel blends (Muralidharan, Vasudevan, \& Sheeba, 2011). The results indicated that the maximum engine output power is for B00 at $1500 \mathrm{rpm}$ at full load reaching $11.5 \mathrm{~kW}$. The maximum decrease in output power is $30.8 \%$ (lower than diesel fuel ) for B100 at $1500 \mathrm{rpm}$ at $75 \%$ load.

Brake Mean Effective Pressure versus Engine load

Brake Mean Effective Pressure (BMEP) is directly proportional to Bp and inversely proportional to engine speed. For the same engine speed, the engine output power increases as long as the engine load increases, consequently BMEP also increases as shown in Fig.4. For the same engine output power not at the same load, BMEP decreased with the increase in engine speed. Figure 5 shows the variation of BMEP versus engine speed for Diesel and biodiesel fuel blends at full load. BMEP decreases with the increase in the percentage of biodiesel fuel in the blends. This is because of the effect of fuel blends on Bp, Which is directly proportional to BMEP at a given speed. The test results show that the maximum value of BMEP reaches 5.3 bar for B00 at $1000 \mathrm{rpm}$ at full load. The minimum value of BMEP reaches 1.05 bar for B100 at 1500 $\mathrm{rpm}$ at $25 \%$ load. The maximum decrease in BMEP is $23 \%$ (lower than diesel fuel) for B100 at $1500 \mathrm{rpm}$ at $75 \%$ load.

Brake Specific Fuel Consumption versus engine load

Brake Specific Fuel Consumption (BSFC) decreased with the increase in engine speed, reaches the minimum, and then increases at high speeds, as shown in Fig.6. At low speeds, the longer time per cycle allows more heat loss and BSFC goes up. At high speeds, BSFC increases due to greater friction losses. In general, there is a decrease in the BSFC with an increase in engine load as shown in Fig.7. One possible explanation for this reduction could be due to the higher percentage of increase in brake power with the load as compared to fuel consumption. But there is a slight increase at full load, this is due to lower volumetric efficiency at high load. BSFC increases with the increase in the percentage of biodiesel fuel in the blends. This is maybe ascribed to the reduction in heating value with increasing biodiesel fuel in the blends (Lin, Huang, \& Huang, 2009). Therefore, a higher rate of fuel should be injected to maintain the generated power. The test results show that, the maximum value of BSFC reaches $872\left(\mathrm{~g} \cdot \mathrm{kW}^{-1} \cdot \mathrm{hr}^{-1}\right)$ for B100 at $1500 \mathrm{rpm}$ at $25 \%$ load. The minimum value of BSFC reaches $254\left(\mathrm{~g} . \mathrm{kW}^{-1} \cdot \mathrm{hr}^{-1}\right)$ for B00 at $1000 \mathrm{rpm}$ at full load. B20 is the optimum fuel blends as compared to the entire test which has nearest values of BSFC to Diesel fuel. The maximum increase in BSFC is 32.18 \% (over than diesel fuel) for B100 at $1500 \mathrm{rpm}$ at $25 \%$ load.

Air to Fuel Ratio versus Engine Load

The stoichiometric air to fuel ratio (AFR) for Diesel fuel is 14.6:1, but the actual AFR is located in the range 18 to 70, which appears that the mixture of diesel engine usually in the lean side. The AFR increased with the increase in engine speed, reaches the maximum, and then decreases at high speed as shown in Fig.8. At low speed, more heat losses are presented, which contributed to more fuel is consumed. At high speed, BSFC also increases due to greater friction losses. The AFR decreased with the increase in engine load, as shown in Fig.9. This is because of the fuel inducted per cycle increases when the engine load increases under both constant engine speed and unchanged inlet-air induction for the combustion process. Also, the AFR is gradually decreased as the biodiesel increases in the fuel blends. This may be due to the oxygen content in fuel blends, which led to lower consumption in the amount of air.

The test results indicated that, the maximum value of the AFR ratio reaches 54.9:1 for B00 at $1500 \mathrm{rpm}$ 
at no-load condition. The minimum amount of AFR reaches 22.9:1 for B80 at $1500 \mathrm{rpm}$ at full load. The maximum decrease in AFR is $18 \%$ (lower than diesel fuel) for B20 at $1500 \mathrm{rpm}$ at no-load.

Excess air factor versus Engine Load

Excess air factor is close to air to fuel ratio curve. From Fig.10 can be observed the excess air factor trends, it's increased at low speeds, reached the maximum and decreased at high speeds. This is because of high specific fuel consumption at low and high speeds by heat loss and friction power, respectively. Figure 11 shows the excess air factor decreased with the increase in engine load due to increases the fuel mass flow rate required to increase the heat release rate to overcoming engine load. Also, the excess air factor increased as the biodiesel fuel increases in the blends. This may be due to the oxygen content in fuel blends, which led to lower consumption in the amount of air. Also, the stoichiometric AFR of biodiesel fuel blends less than stoichiometric AFR of Diesel fuel. Therefore, the excess air factor depends on the stoichiometric AFRs, which lower in the case of biodiesel fuel blends. This leads to excess air factor increased as the biodiesel fuel increases in the blends.

The test results indicated that, the maximum value of Excess air factor reaches 3.7 for B100 at $1500 \mathrm{rpm}$ at no-load condition. The minimum value of Excess air factor reaches 1.7 for B20 at $1500 \mathrm{rpm}$ at full load. The maximum increase in excess air factor is $16.5 \%$ (over than diesel fuel) for B100 at $1500 \mathrm{rpm}$ at $75 \%$ load.

\section{Brake Thermal Efficiency versus Engine Load}

The brake thermal efficiency is simply the inverse of the product of the brake specific fuel consumption and the lower heating value of the fuel. From Fig.12 it can be observed that brake thermal efficiency increased with the increase in engine speeds, reaches the maximum, and then decreases at high speeds. This is because of high specific fuel consumption at low and high speeds by heat losses and friction power, respectively. Figure 13 shows the brake thermal efficiency increased with the increase in engine load due to increase in power developed with the increase in engine load. While there is a slight drop at the full load, this drop possibly due to lowers volumetric efficiency at high load. Brake thermal efficiency decreased with increase in percentage of biodiesel fuel in the blends. This decrease in thermal efficiency can be attributed to the poor combustion characteristics of the blends due to their relatively high viscosity and poor volatility. Also, due to increases of BSFC of biodiesel blends than that of Diesel fuel.

The test results indicated that, the maximum value of brake thermal efficiency reaches $31.8 \%$ for B00 at $1000 \mathrm{rpm}$ at full load. The minimum amount of brake thermal efficiency reaches $10.5 \%$ for B100 at 1500 $\mathrm{rpm}$ at $25 \%$ load. The maximum decrease in brake thermal efficiency is $21 \%$ (lower than diesel fuel) for B80 at $1500 \mathrm{rpm}$ at $75 \%$ load.

\section{Exhaust gas temperature}

The exhaust gas temperature indicates the amount of waste heat going with exhaust gases. The exhaust gas temperature increases with increase in the engine speed, as shown in Fig.14. This is due to increases in the amounts of air and fuel are entering the cylinder with an increase in engine speed. This meaning that, more amount of fuel is burned at high speed, which leads to increasing of exhaust gas temperature at high speed. Figure 15 shows the exhaust gas temperature increases with increases in engine load. This is due to more amount of fuel is required in the engine, to generate the extra power needed to take up the additional loading. Exhaust gas temperature increased with increases in biodiesel fuel percentage in the blends. This is due to a shorter ignition delay and thus longer premixed combustion and mixing controlled combustion phase. Consequently, a maximum heat release rate occurs earlier in biodiesel fuel blends cases, which led to more increases in gas temperature inside the cylinder at the end of the compression stroke. Therefore, an extra increase in exhaust gas temperature occurs due to an isentropic relationship between the exhaust gas temperature and the gas temperature inside the cylinder through exhaust stroke. Another reason, increased quantity of fuel injected for biodiesel fuel and its blends due to lower heating value.

The test results indicated that, the maximum value of brake thermal efficiency reaches $353^{\circ} \mathrm{C}$ for $\mathrm{B} 100$ at 
$1500 \mathrm{rpm}$ at full load. The minimum value of brake thermal efficiency reaches $180{ }^{\circ} \mathrm{C}$ for $\mathrm{B} 00$ at $1500 \mathrm{rpm}$ at no-load condition. The maximum increase in exhaust gas temperature is $44 \%$ for B100 at $1500 \mathrm{rpm}$ at full load.

\section{Volumetric efficiency}

The volumetric efficiency is defined as the mass of air inducted into the engine cylinder divided by the total mass that occupies the displacement volume, at intake manifold density. Figure 16 shows the volumetric efficiency decreases with the increase in engine speed. This due to losses in air flow rate, which occurs at throttling situations as air filter, intake manifold, and intake valves, these losses directly proportional to engine speed(induction airspeed). Figure 17 shows the variation of volumetric efficiency versus engine load for Diesel and biodiesel fuel blends at $1500 \mathrm{rpm}$. For the same engine speed, volumetric efficiency decreases with the increase in engine load. This is due to increase in fuel consumption at high loads to overcoming the engine load, but the same amounts of air are consumed (constant speed) at different loads, leads to increases in gas temperature. Consequently, volumetric efficiency also decreases. The volumetric efficiency of biodiesel and their blends are lower than Diesel fuel. This is due to the higher temperature of the residual gases (from exhaust stroke).

The test results indicated that, the maximum value of volumetric efficiency reaches $75 \%$ for B00 at 1500 $\mathrm{rpm}$ at no-load condition. The minimum value of volumetric efficiency reaches $61.1 \%$ for B100 at $1500 \mathrm{rpm}$ at full load. The maximum decrease for volumetric efficiency is $10.7 \%$ (lower than diesel fuel) for B100 at $750 \mathrm{rpm}$ at full load.

\section{Emission characteristics}

Specific emissions of oxygen, carbon monoxide, carbon dioxide, and oxides of nitrogen versus engine speed and different loads when operated at Diesel/ jatropha biodiesel fuel blends, are illustrated in the following subsections.

\section{Specific Emissions of Oxygen}

The Specific Emissions of Oxygen decreases with increase in engine speed as shown in Fig.18. This is due to an increase in gas temperature inside the cylinder with increasing in engine speed, which leads to more dissociation in $\mathrm{O}_{2}$ atoms being converted to $\mathrm{CO}_{2}$. Figure 19 shows the Specific Emissions of Oxygen decreases with an increase in engine loads. A higher fuel consumption rate was required for higher engine loads. This leads to a larger fuel-to-air ratio under a constant inlet-air consumption rate at constant speed. Hence, lower excess oxygen was produced under a larger engine load. Specific Emissions of Oxygen increases with an increase in the percentage of biodiesel fuel in the blends. This is maybe due to incomplete combustion which produced from bad fuel atomization as results of high viscosity of biodiesel blends. Presence of oxygen in biodiesel fuel composition (about $11 \%$ by volume) may be another reason for this increment.

The test results indicated that, the maximum value of specific emissions of oxygen reaches $7.9 \mathrm{~kg} \mathrm{~kW}^{-1} \mathrm{hr}^{-1}$ for $\mathrm{B} 100$ at $1500 \mathrm{rpm}$ at $25 \%$ load. The minimum value of specific emissions of oxygen reaches $1 \mathrm{~kg} \mathrm{~kW}^{-1} \mathrm{hr}^{-1}$ for B00 at $1500 \mathrm{rpm}$ at full load condition. The maximum increase in specific emissions of oxygen is $33.8 \%$ for B100 at $1500 \mathrm{rpm}$ at $25 \%$ load.

Specific Emissions of Carbon Monoxide

It was found that the specific emissions of carbon monoxide decrease with the increase in engine speed and load as shown in Figs.20 and 21. This is primarily due to the lower gas temperature inside the cylinder under lower engine speed and load, causing slower oxidation conversion of $\mathrm{CO}$ into $\mathrm{CO}_{2}$. Increases engine speed or engine load leads to heighten the reacting gas temperature inside the engine cylinder, which results in a decrease in $\mathrm{CO}$ specific emissions and increases in $\mathrm{CO}_{2}$ specific emissions. Specific emissions of carbon monoxide increase with an increase in the percentage of biodiesel fuel in the blends. This is possible because of the high viscosity of biodiesel fuel blends, leads to more difficulty in the atomization process of biodiesel fuel blends. This resulted in locally rich mixtures in the engine cylinder. In consequence, it caused more 
carbon monoxide generated during the combustion, due to the lack of oxygen, To, fuel richness due to low volumetric efficiency and insufficient oxygen for complete combustion are also responsible for this trend.

The test results indicated that, the maximum value of specific emissions of carbon monoxide reaches 0.0345 $\mathrm{kg} \mathrm{kW}^{-1} \mathrm{hr}^{-1}$ for B100 at $1500 \mathrm{rpm}$ at $25 \%$ load. The minimum value of specific emissions of carbon monoxide reaches $0.006 \mathrm{~kg} \mathrm{~kW}^{-1} \mathrm{hr}^{-1}$ for B00 at $1500 \mathrm{rpm}$ at full load condition. The maximum increase in CO specific emissions is $13.1 \%$ (over than diesel fuel) for B100 at $1500 \mathrm{rpm}$ at $25 \%$ load.

Specific Emissions of Carbon dioxide

The specific emissions of carbon dioxide increase with the increase in engine speed as shown in Fig.22. This is due to, higher engine speed caused to increases of gas temperature in the engine cylinder and more $\mathrm{CO}$ is converted to $\mathrm{CO}_{2}$. The $\mathrm{CO}_{2}$ specific emissions increases with increase in engine load as shown in Fig 23. Because a higher fuel consumption rate was required for larger engine loads heightened the reacting gas temperature inside the engine cylinder. Hence, increases the production of $\mathrm{CO}_{2}$ specific emissions. The specific emissions of carbon dioxide gradually decreased with the increase in biodiesel fuel percentage in the blends. This is attributed to the fact that biodiesel fuel is a low carbon fuel. And has lower elemental carbon to hydrogen ration than Diesel fuel. Leads to burning of biodiesel with air will, therefore, form lower $\mathrm{CO}_{2}$ emission than Diesel fuel.

The test results indicated that, the maximum value of specific emissions of carbon dioxide reaches $1.670 \mathrm{~kg}$ $\mathrm{kW}^{-1} \mathrm{hr}^{-1}$ for $\mathrm{B} 00$ at $1500 \mathrm{rpm}$ at full load. The minimum value of specific emissions of carbon dioxide reaches $0.880 \mathrm{~kg} \mathrm{~kW}^{-1} \mathrm{hr}^{-1}$ for B100 at $1500 \mathrm{rpm}$ at $25 \%$ load. The maximum decrease in $\mathrm{CO}_{2}$ specific emissions is $19.16 \%$ (lower than diesel fuel) for B100 at $1500 \mathrm{rpm}$ at full load.

\section{Specific Emissions of Oxides Nitrogen}

The decreases in excess air factor at high speeds as shown in Fig.10 leads to $\mathrm{N}_{2}$ and $\mathrm{O}_{2}$ atoms also decreased at high speeds, which leads to reductions in $\mathrm{NO}_{\mathrm{x}}$. The turbulence inside the cylinder increases as engine speeds increase, which leads to a faster mixing between fuel and air mixture. The result is the reaction time of each engine cycle was thereafter reduced so that the residence time of the high gas temperature within the cylinder was shortened, which leads to decreases in $\mathrm{NO}_{\mathrm{x}}$. On the contrary, Fig.14 shows the increases in exhaust gas temperature as engine speed increased (as a result of an increase in the inside gas temperature); consequently, $\mathrm{NO}_{\mathrm{x}}$ formation increases.

From Fig.24 can be observed that the specific emissions of $\mathrm{NO}_{\mathrm{x}}$ decrease with the increase in engine speed. This is probably due to the decreasing in oxygen and nitrogen atoms and residence time with the increase in engine speed. The constant engine speed leads to roughly constant residence time. The increase in engine load requires a greater fuel consumption rate. This leads to higher gas temperature and thus greater $\mathrm{NO}_{\mathrm{x}}$ production rate. On the contrary, Fig.11 shows the decreases in excess air factor at high loads leads to $\mathrm{N}_{2}$ and $\mathrm{O}_{2}$ atoms also decreased, which leads to decreases in $\mathrm{NO}_{\mathrm{x}}$. From Fig.25 can be observed that the specific emissions of $\mathrm{NO}_{\mathrm{x}}$ increase with the increased engine load. This is probably because of the rise in gas temperature with increase in engine load. From Fig.24 specific emissions of oxide of nitrogen increase with the increase in biodiesel fuel percentage in the blends. This increase in specific emissions of oxide of nitrogen may be related to the oxygen content of biodiesel. At elevated flame temperature, this oxygen reacts with nitrogen and tends to form $\mathrm{NO}_{\mathrm{x}}$.

The test results indicated that, the maximum value of specific emissions of oxides nitrogen reaches 0.028 $\mathrm{kg} \mathrm{kW}^{-1} \mathrm{hr}^{-1}$ for B100 at $500 \mathrm{rpm}$ at full load. The minimum value of specific emissions of oxides nitrogen reaches $0.004 \mathrm{~kg} \mathrm{~kW}^{-1} \mathrm{hr}^{-1}$ for $\mathrm{B} 00$ at $1500 \mathrm{rpm}$ at $25 \%$ load. The maximum increase in $\mathrm{NO}_{\mathrm{x}}$ specific emissions is $47.3 \%$ (over than diesel fuel) for B100 at $500 \mathrm{rpm}$ at full load.

Conclusion

The present study was carried on an unmodified diesel engine which was converted to run on a dualmode operation. The main objective of this was to evaluate the performance, combustion, and emission 
characteristics of the engine. The engine was operated successfully using pure methyl ester of jatropha oil or it is blended with diesel fuel. The result shows that the engine performance and emissions with biodiesel of Jatropha and its blends were comparable to the performance with diesel fuel.

Biodiesel blends result in decreases of brake power; the maximum reductions occur for B100 at $75 \%$ load at $1500 \mathrm{rpm}$ by $30.8 \%$ as compared to pure Diesel fuel. The biodiesel blends led to declines in air to fuel ratio by $18 \%$ as compared to Diesel fuel, decreases in brake thermal efficiency by $21 \%$ and increases in brake specific fuel consumption by $32.18 \%$.

Biodiesel fuel blends result in a decrease of volumetric efficiency; the maximum decrease occurs for B100 at full load at $750 \mathrm{rpm}$ by $10.7 \%$. The exhaust gas temperature increases with the biodiesel fuel blends by 44 $\%$ for B100 at $1500 \mathrm{rpm}$ at full load.

Specific emission of oxygen increases with increasing the percentage of biodiesel in fuel blends. The maximum increase in specific emissions of oxygen is $33.8 \%$ for B100 at $1500 \mathrm{rpm}$ at $25 \%$ load. Specific emission of CO increases with increasing the percentage of biodiesel in fuel blends by $13.1 \%$ (over than diesel fuel) for B100 at $1500 \mathrm{rpm}$ at $25 \%$ load. Specific emission of $\mathrm{CO}_{2}$ decreases with increasing the percentage of biodiesel in fuel blends by $19.16 \%$ (lower than diesel fuel) for B100 at $1500 \mathrm{rpm}$ at full load. Specific emission of NOx increases with increasing the percentage of biodiesel in fuel blends by $47.3 \%$ (over than diesel fuel) for B100 at $500 \mathrm{rpm}$ at full load.

\section{References}

Agarwal, A. K., Singh, A. P., \& Maurya, R. K. (2017). Evolution, challenges and path forward for low temperature combustion engines.Prog. Energy Combust. Sci., 61 , 1-56. https://doi.org/10.1016/j.pecs.2017.02.001

Agarwal, D., \& Agarwal, A. K. (2007). Performance and emissions characteristics of Jatropha oil (preheated and blends) in a direct injection compression ignition engine. Appl. Therm. Eng., 27 (13), 2314-2323. https://doi.org/10.1016/j.applthermaleng.2007.01.009

Al-Shemmeri, T., \& Oberweis, S. (2011). Correlation of the NOx emission and exhaust gas temperature for biodiesel. Appl. Therm. Eng. , 31 (10), 1682-1688. https://doi.org/10.1016/j.applthermaleng.2011.02.010

Alptekin, E., Canakci, M., Ozsezen, A. N., Turkcan, A., \& Sanli, H. (2015). Using waste animal fat based biodiesels-bioethanol-diesel fuel blends in a DI diesel engine. Fuel, 157, 245-254. https://doi.org/10.1016/j.fuel.2015.04.067

Ambat, I., Srivastava, V., \& Sillanpaa, M. (2018). Recent advancement in biodiesel production methodologies using various feedstock: A review.Renewable Sustainable Energy Rev., 90 , 356-369. https://doi.org/10.1016/j.rser.2018.03.069

Amid, S., Aghbashlo, M., Tabatabaei, M., Hajiahmad, A., Najafi, B., Ghaziaskar, H. S., . . . Mohammadi, P. (2020). Effects of waste-derived ethylene glycol diacetate as a novel oxygenated additive on performance and emission characteristics of a diesel engine fueled with diesel/biodiesel blends. Energy Conversion and Management, 203 , 112245. https://doi.org/10.1016/j.enconman.2019.112245

Arif, M., Bai, Y., Usman, M., Jalalah, M., Harraz, F. A., Al-Assiri, M. S., Zhang, C. (2020). Highest accumulated microalgal lipids (polar and non-polar) for biodiesel production with advanced wastewater treatment: Role of lipidomics. Bioresource Technology, 298 , 122299. https://doi.org/10.1016/j.biortech.2019.122299

Ashour, M. K., \& Elwardany, A. E. (2020). Addition of two kerosene-based fuels to diesel-biodiesel fuel: Effect on combustion, performance and emissions characteristics of CI engine. Fuel, 269 , 117473. https://doi.org/10.1016/j.fuel.2020.117473

Atabani, A., Mahlia, T., Masjuki, H., Badruddin, I. A., Yussof, H. W., Chong, W., \& Lee, K. T. (2013). A comparative evaluation of physical and chemical properties of biodiesel synthesized from edible and non-edible oils and study on the effect of biodiesel blending.Energy, 58 , 296-304. https://doi.org/10.1016/j.energy.2013.05.040 
Balat, M. (2011). Potential alternatives to edible oils for biodiesel production-A review of current work. Energy Convers. Manage., 52 (2), 1479-1492. https://doi.org/10.1016/j.enconman.2010.10.011

Bhuiya, M., Rasul, M., Khan, M., Ashwath, N., \& Azad, A. (2016). Prospects of 2nd generation biodiesel as a sustainable fuel-Part: 1 selection of feedstocks, oil extraction techniques and conversion technologies. Renewable Sustainable Energy Rev., 55 , 1109-1128. https://doi.org/10.1016/j.rser.2015.04.163

Chauhan, B. S., Kumar, N., \& Cho, H. M. (2012). A study on the performance and emission of a diesel engine fueled with Jatropha biodiesel oil and its blends. Energy, 37 (1), 616-622. https://doi.org/10.1016/j.energy.2011.10.043

Chauhan, B. S., Kumar, N., Du Jun, Y., \& Lee, K. B. (2010). Performance and emission study of preheated Jatropha oil on medium capacity diesel engine. Energy, 35 (6), 2484-2492. https://doi.org/10.1016/j.energy.2010.02.043

Che Mat, S., Idroas, M. Y., Hamid, M. F., \& Zainal, Z. A. (2018). Performance and emissions of straight vegetable oils and its blends as a fuel in diesel engine: A review. Renewable and Sustainable Energy Reviews, 82, 808-823. https://doi.org/10.1016/j.rser.2017.09.080

Damodharan, D., Sathiyagnanam, A., Rana, D., Kumar, B. R., \& Saravanan, S. (2018). Combined influence of injection timing and EGR on combustion, performance and emissions of DI diesel engine fueled with neat waste plastic oil. Energy Convers. Manage., 161 , 294-305. https://doi.org/10.1016/j.enconman.2018.01.045

Datta, A., \& Mandal, B. K. (2017). Engine performance, combustion and emission characteristics of a compression ignition engine operating on different biodiesel-alcohol blends. Energy, 125 , 470-483. https://doi.org/10.1016/j.energy.2017.02.110

Debnath, B. K., Sahoo, N., \& Saha, U. K. (2013). Adjusting the operating characteristics to improve the performance of an emulsified palm oil methyl ester run diesel engine. Energy Convers. Manage., 69 , 191-198. https://doi.org/10.1016/j.enconman.2013.01.031

Devaraj, A., Yuvarajan, D., \& Vinoth Kanna, I. (2020). Study on the outcome of a cetane improver on the emission characteristics of a diesel engine. International Journal of Ambient Energy, 41 (7), 798-801. https://doi.org/10.1080/01430750.2018.1492452

Dharma, S., Ong, H. C., Masjuki, H., Sebayang, A., \& Silitonga, A. (2016). An overview of engine durability and compatibility using biodiesel-bioethanol-diesel blends in compression-ignition engines.Energy Convers. Manage., 128 , 66-81. https://doi.org/10.1016/j.enconman.2016.08.072

Franco, Z., \& Nguyen, Q. D. (2011). Flow properties of vegetable oil-diesel fuel blends. Fuel, 90 (2), 838-843. https://doi.org/10.1016/j.fuel.2010.09.044

Gad, M. S., \& Jayaraj, S. (2020). A comparative study on the effect of nano-additives on the performance and emissions of a diesel engine run on Jatropha biodiesel. Fuel, 267, 117168. https://doi.org/10.1016/j.fuel.2020.117168

Hoekman, S. K., Broch, A., Robbins, C., Ceniceros, E., \& Natarajan, M. (2012). Review of biodiesel composition, properties, and specifications.Renewable Sustainable Energy Rev., 16 (1), 143-169. https://doi.org/10.1016/j.rser.2011.07.143

Jakub, Č., Martin, P., Bohuslav, P., Michal, H., Daniel, M., \& Radek, P. (2018). Effect of BiobutanolSunflower Oil-Diesel Fuel Blends on Combustion Characteristics of Compression Ignition Engine. Acta Technologica Agriculturae, 21 (4), 130-135. https://doi.org/10.2478/ata-2018-0024

Jayed, M., Masjuki, H., Kalam, M., Mahlia, T., Husnawan, M., \& Liaquat, A. (2011). Prospects of dedicated biodiesel engine vehicles in Malaysia and Indonesia. Renewable Sustainable Energy Rev., 15 (1), 220-235. https://doi.org/10.1016/j.rser.2010.09.002 
Jiaqiang, E., Pham, M., Zhao, D., Deng, Y., Le, D., Zuo, W., . . . Zhang, Z. (2017). Effect of different technologies on combustion and emissions of the diesel engine fueled with biodiesel: A review.Renewable Sustainable Energy Rev., 80 , 620-647. https://doi.org/10.1016/j.rser.2017.05.250

Kavitha, K. R., Beemkumar, N., \& Rajasekar, R. (2019). Experimental investigation of diesel engine performance fuelled with the blends of Jatropha curcas, ethanol, and diesel. Environ. Sci. Pollut. Res. , 1-7. https://doi.org/10.1007/s11356-019-04288-x

Li, H., Yang, W., Zhou, D., \& Yu, W. (2019). Skeletal mechanism construction for heavy saturated methyl esters in real biodiesel fuels.Fuel, 239 , 263-271. https://doi.org/10.1016/j.fuel.2018.11.020

Lin, B.-F., Huang, J.-H., \& Huang, D.-Y. (2009). Experimental study of the effects of vegetable oil methyl ester on DI diesel engine performance characteristics and pollutant emissions. Fuel, 88 (9), 1779-1785. https://doi.org/10.1016/j.fuel.2009.04.006

Madiwale, S., Karthikeyan, A., \& Bhojwani, V. (2018). Properties investigation and performance analysis of a diesel engine fuelled with Jatropha, Soybean, Palm and Cottonseed biodiesel using Ethanol as an additive. Mater. Today: Proc., 5 (1), 657-664. https://doi.org/10.1016/j.matpr.2017.11.130

Mahdavi, M., Abedini, E., \& Darabi, A. h. (2015). Biodiesel synthesis from oleic acid by nano-catalyst ( $\mathrm{ZrO} 2 / \mathrm{Al} 2 \mathrm{O} 3$ ) under high voltage conditions. $R S C$ Adv., 5 (68), 55027-55032. https://doi.org/10.1039/C5RA07081C

Mahmudul, H., Hagos, F., Mamat, R., Adam, A. A., Ishak, W., \& Alenezi, R. (2017). Production, characterization and performance of biodiesel as an alternative fuel in diesel engines-A review. Renewable Sustainable Energy Rev., 72 , 497-509. https://doi.org/10.1016/j.rser.2017.01.001

Misra, R., \& Murthy, M. (2011). Performance, emission and combustion evaluation of soapnut oil-diesel blends in a compression ignition engine. Fuel, 90 (7), 2514-2518. https://doi.org/10.1016/j.fuel.2011.03.003

Muralidharan, K., Vasudevan, D., \& Sheeba, K. (2011). Performance, emission and combustion characteristics of biodiesel fuelled variable compression ratio engine. Energy, 36 (8), 5385-5393. https://doi.org/10.1016/j.energy.2011.06.050

Najafi, G. (2018). Diesel engine combustion characteristics using nano-particles in biodiesel-diesel blends. Fuel, 212 , 668-678. https://doi.org/10.1016/j.fuel.2017.10.001

Prasad, S. S., Singh, A., \& Prasad, S. J. R. E. (2020). Degummed Pongamia oil-Ethanol microemulsions as novel alternative CI engine fuels for remote Small Island Developing States: Preparation, characterization, engine performance and emissions characteristics.Renewable Energy, 150 , 401-411. https://doi.org/10.1016/j.renene.2019.12.150

Seraç, M. R., Aydın, S., Yılmaz, A., \& Şevik, S. (2020). Evaluation of comparative combustion, performance, and emission of soybean-based alternative biodiesel fuel blends in a CI engine. Renewable Energy, 148 , 1065-1073. https://doi.org/10.1016/j.renene.2019.10.090

Sharma Dugala, N., Singh Goindi, G., \& Sharma, A. (2020). Evaluation of physicochemical characteristics of Mahua (Madhuca indica) and Jatropha (Jatropha curcas) dual biodiesel blends with diesel. Journal of King Saud University - Engineering Sciences . https://doi.org/10.1016/j.jksues.2020.05.006

Silitonga, A., Atabani, A., Mahlia, T., Masjuki, H., Badruddin, I. A., \& Mekhilef, S. (2011). A review on prospect of Jatropha curcas for biodiesel in Indonesia. Renewable Sustainable Energy Rev., 15 (8), 3733-3756. https://doi.org/10.1016/j.rser.2011.07.011

Tariq, M., Ali, S., \& Khalid, N. (2012). Activity of homogeneous and heterogeneous catalysts, spectroscopic and chromatographic characterization of biodiesel: a review. Renewable Sustainable Energy Rev., 16 (8), 6303-6316. https://doi.org/10.1016/j.rser.2012.07.005 
Turkkul, B., Deliismail, O., \& Seker, E. (2020). Ethyl esters biodiesel production from Spirulina sp. and Nannochloropsis oculata microalgal lipids over alumina-calcium oxide catalyst. Renewable Energy, 145 , 1014-1019. https://doi.org/10.1016/j.renene.2019.06.093

Uyumaz, A. (2020). Experimental evaluation of linseed oil biodiesel/diesel fuel blends on combustion, performance and emission characteristics in a DI diesel engine. Fuel, 267, 117150. https://doi.org/10.1016/j.fuel.2020.117150

Verma, P., Dwivedi, G., Behura, A. K., Patel, D. K., Verma, T. N., \& Pugazhendhi, A. (2020). Experimental investigation of diesel engine fuelled with different alkyl esters of Karanja oil. Fuel, 275 , 117920. https://doi.org/10.1016/j.fuel.2020.117920

Xiao, H., Guo, F., Wang, R., Yang, X., Li, S., \& Ruan, J. (2020). Combustion performance and emission characteristics of diesel engine fueled with iso-butanol/biodiesel blends. Fuel, 268, 117387. https://doi.org/10.1016/j.fuel.2020.117387

Figure Captions

Fig. 1 Schematic diagram of the experimental system

Fig. 2 Brake power versus engine speed for diesel and biodiesel fuel at full load

Fig. 3 Brake power versus engine load for diesel and biodiesel fuel at $1500 \mathrm{rpm}$

Fig. 4 Brake Mean Effective Pressure versus engine load for diesel and biodiesel fuel at $1500 \mathrm{rpm}$

Fig. 5 Brake Mean Effective Pressure versus engine speed for diesel and biodiesel fuel at full load

Fig. 6 Brake Specific Fuel Consumption versus engine speed for diesel and biodiesel fuel at full load

Fig. 7 Brake Specific Fuel Consumption versus engine load for diesel and biodiesel fuel at $1500 \mathrm{rpm}$

Fig. 8 Air to fuel ratio versus engine speed for diesel and biodiesel fuel at full load

Fig. 9 Air to fuel ratio versus engine load for diesel and biodiesel fuel at $1500 \mathrm{rpm}$

Fig. 10 Excess air factor versus engine speed for diesel and biodiesel fuel at full load

Fig. 11 Excess air factor versus engine load for diesel and biodiesel fuel at $1500 \mathrm{rpm}$

Fig. 12 Brake thermal efficiency versus engine speed for diesel and biodiesel fuel at full load

Fig. 13 Brake thermal efficiency versus engine load for diesel and biodiesel fuel at $1500 \mathrm{rpm}$

Fig. 14 Exhaust gas temperature versus engine speed for diesel and biodiesel fuel at full load

Fig. 15 Exhaust gas temperature versus engine load for diesel and biodiesel fuel at $1500 \mathrm{rpm}$

Fig. 16 Volumetric efficiency versus engine speed for diesel and biodiesel fuel at full load

Fig. 17 Volumetric efficiency versus engine load for diesel and biodiesel fuel at $1500 \mathrm{rpm}$

Fig. 18 Specific Emissions of Oxygen versus engine speed at full load

Fig. 19 Specific Emissions of Oxygen versus engine load at $1500 \mathrm{rpm}$

Fig. 20 Specific Emissions of Carbon Monoxide versus engine speed at full load

Fig. 21 Specific Emissions of Carbon Monoxide versus engine load at $1500 \mathrm{rpm}$

Fig. 22 Specific Emissions of Carbon dioxide versus engine speed at full load

Fig. 23 Specific Emissions of Carbon dioxide versus engine load at $1500 \mathrm{rpm}$

Fig. 24 Specific Emissions of Oxides Nitrogen versus engine speed at full load 
Fig. 25 Specific Emissions of Oxides Nitrogen versus engine load at $1500 \mathrm{rpm}$

\section{Hosted file}

TABLES.docx available at https://authorea.com/users/336965/articles/462641-a-study-on-theperformance-and-emission-of-diesel-engine-with-jatropha-biodiesel-and-its-blends-atdifferent-engine-load

\section{Hosted file}

FIGURES.docx available at https://authorea.com/users/336965/articles/462641-a-study-on-theperformance-and-emission-of-diesel-engine-with-jatropha-biodiesel-and-its-blends-atdifferent-engine-load 